\title{
LITERASI KEUANGAN PADA SISWA SEKOLAH DASAR DI KOTA DEPOK, PROVINSI JAWA BARAT, INDONESIA
}

\author{
Yulial Hikmah \\ Program Studi Administrasi Asuransi dan Aktuaria, Program Pendidikan Vokasi, Universitas Indonesia, Depok, \\ Indonesia \\ *Penulis Korespondensi : yulialhikmah47@ui.ac.id
}

\begin{abstract}
Abstrak
Menurut Kementerian Pendidikan dan Kebudayaan, Indonesia, Pendidikan literasi keuangan sangat diperlukan untuk mendidik manusia sadar dan paham tentang bagaimana cara mengelola keuangan secara bijak. Pendidikan literasi keuangan harus diberikan sedini mungkin kepada anak terutama pada anak usia pra sekolah dan sekolah dasar. Studi dari University of Cambridge mengungkapkan bahwa anak-anak mulai membentuk kebiasaan finansial sejak usia 7 tahun. Oleh karena itu, penelitian ini melaksanakan serangkaian kegiatan literasi keuangan untuk siswa sekolah dasar, yaitu menonton video edukasi animasi, simulasi permainana monopoli ramah anak, simulasi menabung dan membuat anggaran, serta wisata edukasi ke Museum Bank Indonesia. Kegiatan literasi diharapkan mampu meningkatkan kecerdasan finansial anak. Penelitian ini menggunakan uji beda rata-rata statistik untuk menemukan apakah rangkaian kegiatan literasi finansial meningkatkan kecerdasan finansial atau tidak. Sebelum melakukan uji beda mean, dilakukan uji kenormalan data. Jika data tidak normal maka digunakan uji beda mean Wilcoxon. Hasil pengujian menunjukkan bahwa kegiatan literasi keuangan dapat meningkatkan kecerdasan siswa sekolah dasar.
\end{abstract}

Kata kunci: Kecerdasan Finansial; Permaninan Monopoli Ramah Anak; Uji Beda Mean Wilcoxon.

\begin{abstract}
Based on Kementerian Pendidikan dan Kebudayaan Republik Indonesia, financial literacy education is needed to educate people to be aware and understand how to manage finances wisely. Financial literacy education must be given as early as possible to the children, especially in pre-school and elementary school. A study from the University of Cambridge results that the children begin to form the financial habits from the age of 7 years old. Therefore, this study conducted a series of financial literacy activities to elementary school students, namely watching animated education videos, simulating childfriendly monopoly game, saving simulations and making budgets, and educational tours to the Bank Indonesia Museum. Literacy activities are expected to increase children's financial intelligence. This study uses a statistical mean difference test to find out whether a series of financial literacy activities increase financial intelligence or not. Before conducting the mean difference test, a normality test is performed. If the data don't spread normally then used the Wilcoxon mean different test. The test results show that financial literacy activities can improve the financial intelligence of elementary school students.
\end{abstract}

Keywords: Financial Literacy; Child-Friendly Monopoly Game; Wilcoxon Mean Difference Test.

\section{PENDAHULUAN}

Forum Ekonomi Dunia mengamanatkan agar pemerintahan di dunia meningkatkan kemampuan warga negaranya untuk memiliki keterampilan di abad 21 meliputi literasi dasar, kompetensi dan karakter. Salah satu upaya yang dilakukan Kementerian Pendidikan dan Kebudayaan yaitu menginisiasi pelaksanaan Gerakan Literasi Nasional (GLN). Oleh karena itu, menjadi keharusan bagi masyarakat Indonesia untuk pembangunan abad 21, menguasai enam literasi dasar yaitu literasi bahasa, literasi numerasi, literasi sains, literasi digital, literasi finansial dan literasi budaya dan kewarganegaraan.
Pendidikan literasi keuangan sangat diperlukan untuk mendidik manusia sadar dan paham tentang bagaimana cara mengelola keuangan secara bijak dan sesuai kebutuhan. Pendidikan literasi keuangan harus diberikan sedini mungkin kepada anak terutama pada anak usia pra sekolah dan sekolah dasar (Kementerian Pendidikan dan Kebudayaan Republik Indonesia, 2018).

Direktur Pembinaan Sekolah Dasar (SD) Kementerian Pendidikan dan Kebudayaan (Kemendikbud) Khamim, pada Peluncuran dan Pelatihan Guru Program Pendidikan Cerdas Keuangan Kurikulum 
Cha-Ching, di Kantor Kemendikbud, Jakarta, dasar pengajaran dari Kurikulum Cha-Ching adalah menanamkan empat konsep utama dalam pengelolaan uang, yaitu memperoleh (earn), menyimpan (save), membelanjakan (spend), dan menyumbangkan (donate), dalam kehidupan sehari-hari siswa. Tujuan dari pendidikan keuangan sejak dini adalah memberikan pemahaman dasar mengenai pentingnya nilai uang sehingga anak-anak diharapkan bisa membuat keputusan finansial yang lebih baik saat dewasa. Kurikulum Cha-Ching ini sejalan dengan studi dari University of Cambridge yang mengungkapkan bahwa anak-anak mulai membentuk kebiasaan finansial sejak usia 7 tahun (Zubaidah, 2019).

Menurut psikolog Stefanie Pekasa M. Psi, Kecerdasan finansial anak dapat diberikan saat anak sudah mulai diberikan uang saku sekolah. Maksud dari pemberian uang saku bukan pada besar atau kecil nominalnya, tapi bagaimana mengajarkan anak untuk mulai mengelola uang sendiri. Menurut perencana keuangan Janus Financial, Dwita Ariani, pemberian uang saku merupakan cara mengajarkan anak untuk mengelola uang sedini mungkin. Dengan diberikan tanggung jawab mengelola uang sendiri akan membantu proses pendewasaan anak (Wahyuni, 2017).

Model pembelajaran adalah prosedur atau pola sistematis yang digunakan sebagai pedoman untuk mencapai tujuan pembelajaran di dalamnya terdapat strategi, teknik, metode, bahan, media, dan alat penilaian pembelajaran. Metode pembelajaran adalah cara atau tahapan yang digunakan dalam interaksi antara peserta didik dan pendidik untuk mencapai tujuan pembelajaran yang telah ditetapkan sesuai dengan materi dan mekanisme metode pembelajaran (Afandi dkk, 2013). Salah satu metode pembelajaran adalah simulasi. Metode simulasi memiliki beberapa kelebihan, di antaranya adalah menyenangkan sehingga siswa secara wajar terdorong untuk berpartisipasi, memungkinkan terjadinya interaksi antarsiswa, menimbulkan respon yang positif dari siswa yang lamban, kurang cakap, dan kurang motivasi, serta melatih berpikir kritis bagi siswa (Hasibuan \& Moedjiono, 2008).

Media adalah segala sesuatu yang dapat menyalurkan informasi dari sumber informasi kepada penerima informasi. Manfaat media dalam proses pembelajaran adalah memperlancar interaksi antara guru dengan siswa sehingga kegiatan pembelajaran akan lebih efektif dan efisien (Afandi dkk, 2013). Media pembelajaran adalah semua alat (bantu) atau benda yang digunakan dalam kegiatan belajar mengajar, dengan maksud untuk menyampaikan pesan (informasi) pembelajaran dari sumber (guru maupun sumber lain) kepada penerima (dalam hal ini anak didik ataupun warga belajar). Upaya inovatif yang ditempuh dalam membelajarkan anak adalah penggunaan media yang menarik dan menyenangkan namun tetap edukatif yaitu media pembelajaran education game (Rohwati, 2012). Salah satu kelebihan utama education game adalah pada visualisasi dari permasalahan nyata. Massachusetts institute of Technology (MIT) berhasil membuktikan bahwa game sangat berguna untuk meningkatkan logika dan pemahaman pemain terhadap suatu masalah melalui proyek game yang dinamai Scratch (Vitianingsih, 2016).

Salah satu permainan edukasi yang sering digunakan sebagai media pembelajaran adalah monopoli. Monopoly-Like Game (MLG) dimainkan untuk mendukung tiga kompetensi berdasarkan standar Kurikulum 2013; sikap, psikomotorik, dan kompetensi kognitif. Ada dua manfaat menggunakan game. Pertama, informasi yang disajikan pada kartu dapat mempromosikan siswa untuk menyadari dan mengenali apa yang penting itu. Dengan melakukan itu, mereka dapat mengelola pengetahuan mereka untuk memahami konsep. Selain itu, para siswa juga menggunakan keterampilan mereka dari metode ilmiah untuk menghasilkan hipotesis dan kesimpulan. Dengan kata lain, ini akan mempengaruhi aspek kognitif dan psikomotor secara bersamaan. Kedua, aturan MLG yang ditetapkan oleh siswa dapat membuat mereka jujur dan bertanggung jawab atas peran mereka. Ini mempengaruhi sikap para siswa (Fauziah dkk, 2018).

Hasil belajar merupakan proses perubahan kemampuan intelektual (kognitif), kemampuan minat atau emosi (afektif) dan kemampuan motorik halus dan kasar (psikomotor) pada peserta didik (Afandi $\mathrm{dkk}, 2013$ ). Hasil belajar merupakan hal yang penting yang akan dijadikan tolok ukur keberhasilan siswa dalam belajar dan sejauh mana sistem pembelajaran yang diberikan guru berhasil atau tidak. Suatu proses belajar mengajar dikatakan berhasil apabila kompetensi dasar yang diinginkan tercapai. Untuk mengetahui tercapai tidaknya kompetensi tersebut guru mengadakan tes setelah menyajikan materi pembelajaran kepada siswa. Dari hasil tes ini diketahui sejauh mana keberhasilan siswa dalam belajar (Rohwati, 2012).

Oleh karena itu, penelitian ini merupakan suatu kegiatan literasi keuangan dengan beberapa media dan metode pembelajaran. Pertama, dilakukan edukasi dengan memanfaatkan teknologi yaitu menampilkan video animasi pembelajaran finansial. Kedua, dilakukan simulasi permainan monopoli versi anak yang telah disesuaikan dengan kebutuhan dan keinginan siswa SD. Ketiga, dilakukan simulasi kegiatan menabung dan membuat anggaran selama 2 minggu. Keempat, dilakukan wisata edukasi ke museum Bank Indonesia. Keempat kegiatan tersebut merupakan suatu rangkaian literasi keuangan kepada siswa SD dan dilakukan evaluasi untuk melihat apakah kegiatan literasi keuangan yang diberikan berdampak pada peningkatan pemahaman siswa dalam mengelola keuangan mereka dengan bijak, atau tidak. 


\section{METODE PENELITIAN}

Data penelitian ini adalah data primer yang diberikan kepada siswa-siswa sekolah dasar, sebelum dan setelah pelaksanaan kegiatan literasi keuangan. Jumlah siswa yang menjadi sampel penelitian adalah 73 siswa dengan rincian 35 siswa berasal dari SDN Beji 2 dan 38 siswa berasal dari SDN Pondok Cina 1. Kedua sekolah tersebut dipilih dengan teknik pengambilan sampel cluster bertingkat berdasarkan jarak terdekat dari tempat kerja peneliti. Responden yang dipilih yaitu siswa sekolah dasar kelas 5 SD karena pada usia tersebut diharapkan sudah memiliki pengetahuan dasar tentang uang, menabung, dan mampu melakukan perhitungan dengan baik.

Kegiatan literasi keuangan pada siswa sekolah dasar dilakukan dengan menonton video animasi tentang keuangan, simulasi dengan permainan monopoli ramah anak, simulasi menabung dan membuat anggaran, serta wisata edukasi ke Museum Bank Indonesia. Kegiatan-kegiatan tersebut dirancang sedemikian sehingga siswa sekolah dasar dapat belajar secara visual, audio, dan kinetis (dengan melakukan simulasi). Oleh karena itu, penelitian ini menghipotesiskan bahwa kegiatan literasi keuangan pada penelitian ini dapat meningkatkan literasi keuangan anak yaitu meningkatkan pengetahuan mengenai sejarah uang dan pentingnya menabung, membuat anggaran, serta dapat membedakan keinginan dan kebutuhan sehingga menjadi konsumen yang cerdas mulai sejak dini. Untuk menguji hipotesis maka dilakukan pengukuran secara deskriptif dan inferensia.

Pada tahapan deskriptif, diperoleh gambaran umum kondisi siswa sekolah dasar mengenai kebiasaan menabung dan tingkat pemahaman siswa terhadap kebutuhan dan keinginan. Selanjutnya pada tahapan inferensia dilakukan uji beda mean untuk melihat apakah aktivitas literasi keuangan yang diberikan akan meningkatkan kecerdasan finansial anak atau tidak.

\section{HASIL DAN PEMBAHASAN}

Sampel penelitian sejumlah 73 siswa SD yang berasal dari SDN Beji 2 dan SDN Pondok Cina 1. Berikut ini merupakan gambaran dari kebiasaan siswa sekolah dasar mengenai menabung:

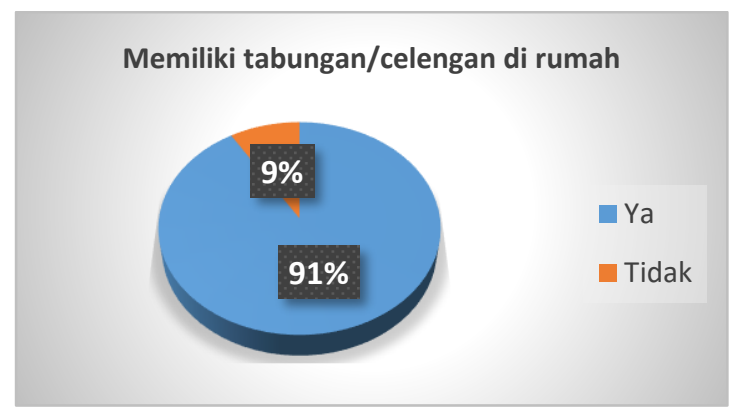

Gambar 1. Ketersediaan Tabungan/Celengan di Rumah.
Berdasarkan Gambar 1 terlihat bahwa 91\% siswa memiliki tabungan atau celengan di rumah. Sedangkan sisanya sebanyak $9 \%$ belum memiliki tabungan atau celengan di rumah. Ini merupakan suatu awal yang baik, artinya siswa SD sudah mengenal tabungan/celengan.

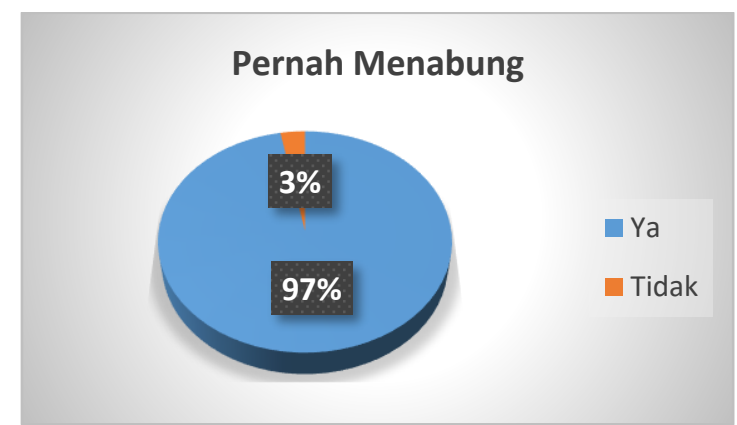

Gambar 2. Pengalaman Menabung.

Berdasarkan Gambar 2 di atas, terlihat bahwa, 97\% siswa sekolah dasar pernah menabung sedangkan sisanya 3\% belum pernah menabung. Artinya, sejak dini, siswa sekolah dasar sudah mempraktikkan kegiatan menabung. Akan tetapi, sebanyak $97 \%$ siswa tidak semuanya masih menabung. Hal ini terlihat pada Gambar 3, yang menunjukkan bahwa hanya $86 \%$ siswa sekolah dasar masih menabung hingga pelaksaan survei. Sisanya sebanyak $14 \%$ siswa sudah tidak menabung lagi.

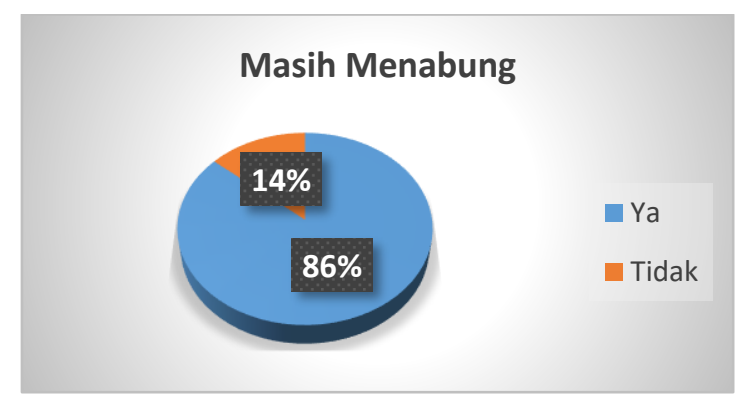

Gambar 3. Kebiasaan Menabung.

Kegiatan literasi keuangan yang dilakukan antara lain penayangan video edukasi animasi mengenai membedakan kebutuhan dan keinginan, belajar menabung, menjadi konsumen yang cerdas dan menggunakan uang dengan bijak, serta mampu membuat anggaran pemasukan dan pengeluaran yang dapat melatih kemampuan berhitung siswa. Selain itu, ditampilkan pula lagu yang berjudul "Yuk Menabung" di sela-sela penayangan video edukasi animasi. Dokumentasi penayangan video edukasi animasi dapat dilihat pada Gambar 4.

Video animasi diperoleh dari akun Youtube "Generasi Cerdas Keuangan", "Shoffa dan Hanna", dan "Rumah Animasi Budi Luhur". Video yang digunakan dalam kegiatan literasi keuangan ini dapat dilihat pada Tabel 1. Penayangan video animasi mengenai keuangan merupakan salah satu penerapan media pembelajaran dengan menggunakan teknologi. Siswa SD mampu menangkap informasi dari video yang diberikan. Hal 
ini ditunjukkan dengan tingginya antuasias siswa yang dapat dilihat pada Gambar 5.

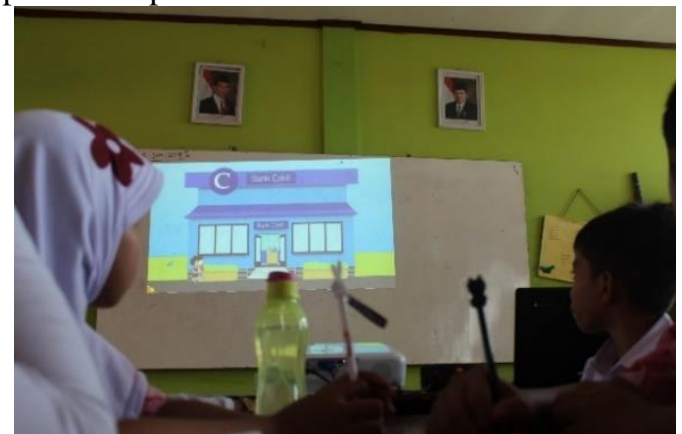

Gambar 4. Penayangan Video Edukasi Animasi tentang Keuangan.

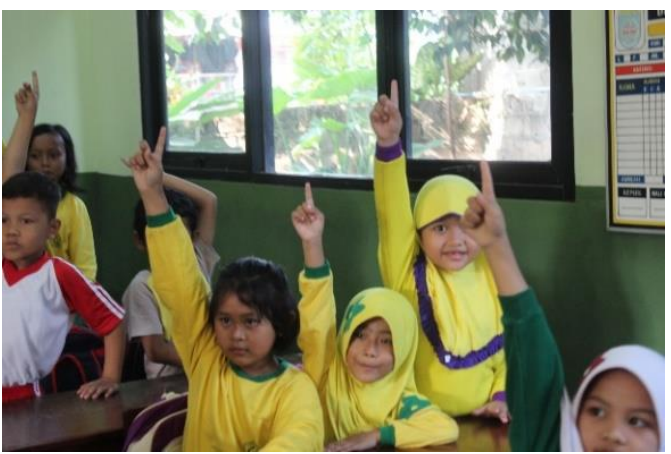

Gambar 5. Antusiasme Siswa SD.

Tabel 1. Video Edukasi Animasi.

\begin{tabular}{lll}
\hline No. & Link Video Youtube & Judul Video \\
\hline 1 & $\begin{array}{l}\text { https://www.youtube.com/watch?v=-YjM9dNJYA4 } \\
\text { (Generasi Cerdas Keuangan, 2019) }\end{array}$ & $\begin{array}{l}\text { Kebutuhan dan Keinginan - } \\
\text { Literasi Keuangan SD }\end{array}$ \\
\hline 2 & $\begin{array}{l}\text { https://www.youtube.com/watch?v=TGZ8R_ZAa1w } \\
\text { (Shoffa dan Hanna, 2018) }\end{array}$ & $\begin{array}{l}\text { S2-E40: MENABUNG YUK } \\
\text { Shoffa Dan Hanna Channel }\end{array}$ \\
\hline 3 & $\begin{array}{l}\text { https://www.youtube.com/watch?v=dSENBwhpIEY } \\
\text { (Rumah Animasi Budi Luhur, 2017) }\end{array}$ & Budi dan Lulu - Yuk Menabung \\
\hline 4 & $\begin{array}{l}\text { https://www.youtube.com/watch?v=TH5conu9Pd4 } \\
\text { (Generasi Cerdas Keuangan, 2019) }\end{array}$ & $\begin{array}{l}\text { Konsumen Cerdas - Literasi } \\
\text { Keuangan SD }\end{array}$ \\
\hline 5 & $\begin{array}{l}\text { https://www.youtube.com/watch?v=OTc8uUkntr0 } \\
\text { (Generasi Cerdas Keuangan, 2019) }\end{array}$ & Anggaran - Literasi Keuangan SD \\
\hline
\end{tabular}

Kegiatan selanjutnya adalah simulasi literasi keuangan melalui permainan monopoli ramah anak. Permainan monopoli ramah anak dibuat dengan menyesuaikan tema literasi keuangan yaitu untuk membedakan keinginan dan kebutuhan. Dokumentasi permainan monopoli ramah anak dapat dilihat pada Gambar 6. Kegiatan literasi keuangan dengan menggunakan monopoli ramah anak merupakan salah satu media pembelajaran dengan permainan edukasi.

Siswa SD mampu mengelola uang mainan monopoli mereka dengan bijaksana, yaitu membedakan kebutuhan dan keinginan, mengutamakan kebutuhan kemudian mengikuti keinginan jika semua kebutuhan sudah terpenuhi, dan belajar menabung. Pembelajaran dengan media permainan edukasi merupakan salah satu metode pembelajaran yang menyenangkan bagi anak sehingga anak menjadi belajar tanpa beban dan dapat menangkap informasi dengan baik.

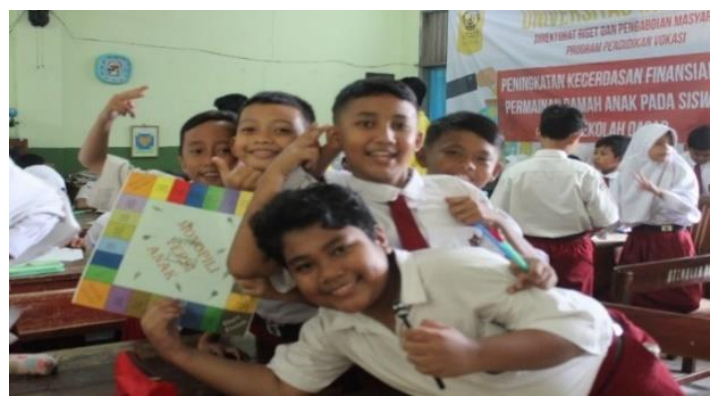

Gambar 6. Permainan Edukasi Monopoli Ramah Anak.
Kegiatan selanjutnya adalah simulasi menabung dan membuat anggaran keuangan yang dapat dilihat pada Gambar 7. Siswa diajarkan membuat anggaran keuangan. Siswa diminta untuk menyisihkan uang mereka di celengan dan membuat anggaran pemasukan dan pengeluaran mereka selama 2 minggu. Para guru turut membantu dalam mengontrol dan mengevaluasi kegiatan menabung dan membuat anggaran pemasukan dan pengeluaran. Kegiatan ini juga mampu meningkatkan kemampuan berhitung dan matematika siswa. Kegiatan ini merupakan metode pembelajaran klasik disertai dengan simulasi praktik. Artinya, siswa diajarkan dengan metode tatap muka kemudian dipraktekkan dalam waktu jangka tertentu, kemudian dikontrol dan dievaluasi oleh para guru. Kegiatan ini sangat membantu siswa terutama dalam memahami arti pentingnya menabung dan mengelola keuangan dengan bijak.

Kegiatan terakhir adalah wisata edukasi ke Museum Bank Indonesia. Kegiatan ini merupakan salah satu perwujudan media pembelajaran di luar sekolah (outdoor). Siswa dapat menyadari bahwa mendapatkan informasi dan pengetahuan tidak harus melalui sekolah. Selain itu, dikarenakan terdapat dua sekolah yang menuju ke museum BI, maka kegiatan wisata edukasi ini juga melatih kemampuan komunikasi antarsiswa yang berbeda sekolah dan menambah teman sepermainan. Dokumentasi Wisata Edukasi ke Museum Bank Indonesia dapat dilihat pada Gambar 8. 


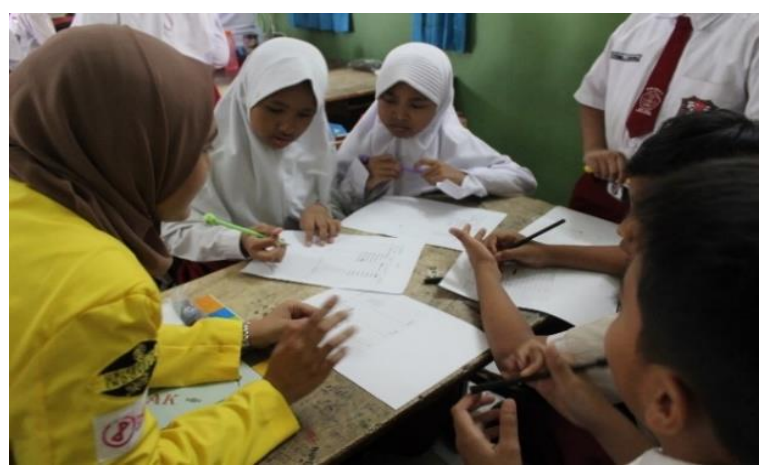

Gambar 7. Belajar Membuat Anggaran Keuangan.

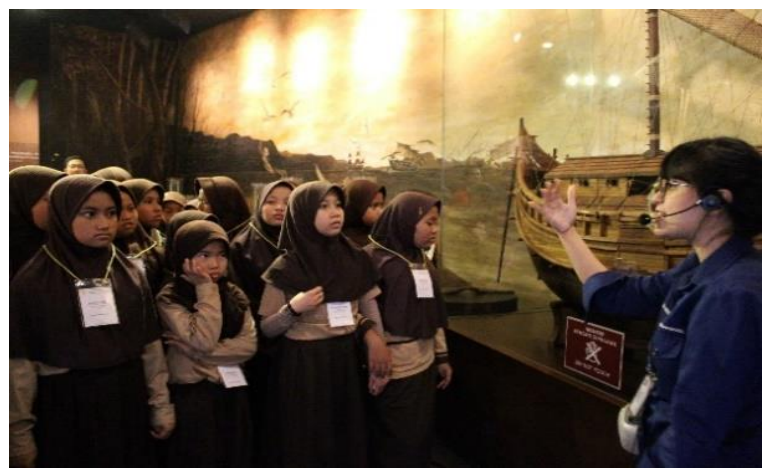

Gambar 8. Wisata Edukasi ke Museum Bank Indonesia.

Untuk mengetahui apakah kegiatan literasi keuangan meningkatkan tingkat pemahaman siswa atau tidak, dilakukan pengumpulan data melalui kuesioner yang diberikan sebelum dan setelah kegiatan literasi keuangan, yang disebut dengan pretest dan posttest.

\section{Average of Pretest and Posttest Scores}

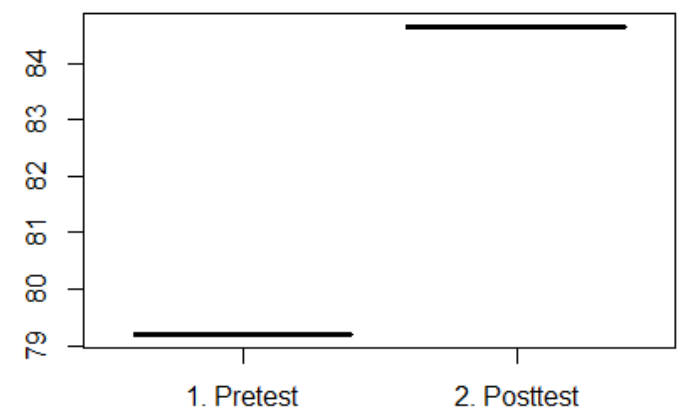

Gambar 8. Rata-Rata Hasil Pretest dan Posttest.

Rata-rata skor pretest siswa adalah 79.2 dengan nilai minimum 42 dan nilai maksimum 95 sedangkan rata-rata skor posttest siswa adalah 84.7 dengan nilai minimum 53 dan nilai maksimum 95. Rata-rata skor pretest dan posttest dapat dilihat pada Gambar 9. Berdasarkan gambar di atas terlihat bahwa kegiatan literasi keuangan dapat menaikkan rataan tingkat pemahaman siswa, karena rataan posttest lebih besar dibandingkan rataan pretest.

Pada bagian sebelumnya telah dilihat secara deskriptif bahwa rataan skor posttest siswa lebih besar dibandingkan rataan skor pretest. Artinya kegiatan literasi keuangan mampu meningkatkan rataan skor 73 siswa, yaitu sebesar 5,5 skor. Selanjutnya, akan dilakukan analisis inferensia, yaitu pengujian beda mean untuk melihat secara umum, apakah terdapat perbedaan rata-rata skor pretest dan posttest dengan menggunakan tingkat kesalahan 5\%.

Metode uji beda mean yang dilakukan tergantung dari sebaran data. Jika data menyebar normal maka digunakan uji beda mean $t$ berpasangan sedangkan jika tidak demikian maka digunakan uji beda mean Wilcoxon. Oleh karena itu, tahapan awal adalah melakukan uji kenormalan dengan Lilliefors (Kolmogorov-Smirnov).

Tabel 2. Hasil Pengujian Lilliefors

$$
\begin{gathered}
\text { p-value } \\
\hline 0,001811 \\
\hline
\end{gathered}
$$

Penelitian ini menggunakan tingkat kesalahan $\alpha=5 \%$ sehingga berdasarkan Tabel 2, diperoleh $p$-value hasil uji $<0,05$, artinya data penelitian tidak berdistribusi normal. Oleh karena itu, untuk mengukur keefektifan kegiatan literasi keuangan yang telah diberikan kepada siswa sekolah dasar, dilakukan uji beda mean Wilcoxon.

Tabel 3. Hasil Pengujian Beda Mean Wilcoxon.

$$
\begin{gathered}
\hline \text { p-value } \\
\hline 0,0000 \\
\hline
\end{gathered}
$$

Penelitian ini menggunakan tingkat kesalahan $\alpha=5 \%$ sehingga berdasarkan Tabel 3 , diperoleh $p$-value hasil uji $<0,05$, artinya kegiatan literasi keuangan ini dapat meningkatkan kecerdasan finansial anak karena diperoleh nilai posttest lebih besar dibandingkan nilai pretest.

Setelah dilakukan pengukuran, maka rangkaian kegiatan literasi keuangan anak pada penelitian ini dapat dijadikan sebagai salah satu media dan metode pembelajaran yang dapat diterapkan di sekolah dasar lainnya. Rangkaian kegiatan tersebut merupakan pembelajaran yang melibatkan visual, audio, dan kinetis dengan menerapkan teknologi yang ada. Simulasi permainan monopoli ramah anak dan menabung dapat meningkatkan pemahaman anak mengenai keinginan dan keuangan serta berlatih menjadi konsumen yang cerdas. Selain itu, simulasi membuat anggaran membuat anak dapat mengendalikan pengeluaran dan pemasukan termasuk tabungannya. Ini juga dapat melatih anak dalam kemampuan berhitung dan matematika. Wisata edukasi juga perlu dilakukan dalam metode pembelajaran di sekolah sebagai wujud pengembangan wawasan di luar sekolah dan dapat meningkatkan keberanian dan kemampuan komunikasi anak karena berinteraksi dengan siswa sekolah lain maupun petugas yang bekerja di tempat wisata edukasi. 


\section{KESIMPULAN}

Berdasarkan pembahasan sebelumnya, diperoleh bahwa 75 siswa SD dari SDN Beji 2 dan SDN Pondok Cina 1, 91\% memiliki tabungan atau celengan di rumah saat ini, 97\% pernah menabung, dan 86\% masih menabung sampai saat ini. Kegiatan literasi keuangan yang dilakukan adalah menonton video edukasi animasi mengenai membedakan kebutuhan dan keinginan, belajar menabung, menjadi konsumen yang cerdas dan belajar membuat anggaran pemasukan dan pengeluaran yang melatih kemampuan berhitung (matematika) siswa. Setelah menonton video edukasi animasi, siswa melakukan simulasi literasi keuangan melalui permainan edukasi monopoli ramah anak. Selanjutnya, siswa melakukan simulasi menabung dan membuat anggaran keuangan. Kegiatan literasi keuangan terakhir adalah wisata edukasi ke museum Bank Indonesia.

Penelitian ini melakukan pengujian tingkat pemahaman siswa mengenai keuangan dengan cara memberikan pertanyaan dalam sebuah kuesioner yang dibagikan sebanyak 2 kali, yaitu sebelum kegiatan literasi keuangan dilakukan (pretest) dan setelah kegiatan literasi keuangan dilakukan (posttest). Hasil menunjukkan bahwa kegiatan literasi keuangan ramah anak yang dilakukan dapat meningkatkan kecerdasan finansial siswa sekolah dasar di Depok. Rangkaian kegiatan literasi keuangan anak pada penelitian ini dapat dijadikan sebagai salah satu media dan metode pembelajaran yang dapat diterapkan di sekolah dasar lainnya. Dengan diterapkannya rangkaian kegiatan literasi keuangan anak di sekolah, diharapkan dapat melahirkan generasi penerus bangsa yang bijak dalam mengelola keuangannya.

\section{DAFTAR PUSTAKA}

Afandi, M., Chamalah, E., \& Wardani, O. (2013). Model dan Metode Pembelajaran di Sekolah. Semarang: Unissula Press.

Fauziah, A., Purnomo, A., Fathonah, N., \& Khusaini. (2018). The Use of Monopoly-Like Game (MLG) to Promote Qualified Scores for Three Student Competencies. Jurnal Pendidikan IPA Indonesia, 7(3), 280-285.

Generasi Cerdas Keuangan. (2019). Anggaran-Literasi Keuangan SD. Dipetik May 15, 2019, dari Youtube:

https://www.youtube.com/watch?v=OTc8uUknt r0

Generasi Cerdas Keuangan. (2019). Kebutuhan dan Keinginan-Literasi Keuangan. Dipetik May 15, 2019, dari Youtube: https://www.youtube.com/watch?v=YjM9dNJYA4

Generasi Cerdas Keuangan. (2019). Konsumen CerdasLiterasi Keuangan SD. Dipetik May 15, 2019, dari Youtube: https://www.youtube.com/watch?v=TH5conu9P d4
Hasibuan, J., \& Moedjiono. (2008). Proses Belajar Mengajar. Bandung: PT Remaja Rosdakarya.

Kementerian Pendidikan dan Kebudayaan Republik Indonesia. (2018). Pentingnya Pengenalan Literasi Keuangan Sejak PAUD. Dipetik May 10, 2019, dari https://anggunpaud.kemdikbud.go.id/index.php/ berita/index/20180525081527/Pentingnya-

Pengenalan-Literasi-Keuangan-Sejak-PAUD

Rohwati, M. (2012). Penggunaan Education Game untuk Meningkatkan Hasil Belajar IPA Biologi Konsep Klasifikasi Makhluk Hidup. Jurnal Pendidikan IPA Indonesia, 1(1), 75-81.

Rumah Animasi Budi Luhur. (2017). Budi dan Lulu-Yuk Menabung. Dipetik May 15, 2019, dari Youtube: https://www.youtube.com/watch?v=dSENBwhp IEY

Shoffa dan Hanna. (2018). S2-E40: MENABUNG YUK | Shoffa Dan Hanna Channel. Dipetik May 15, 2019, dari Youtube: https://www.youtube.com/watch?v=TGZ8R_Z Aa1w

Vitianingsih, A. (2016). Game Edukasi Sebagai Media Pembelajaran Pendidikan Anak Usia Dini. Jurnal INFORM, 1(1), 2502-3470.

Wahyuni, N. (2017). Berapa Uang Saku yang Wajar untuk Anak Zaman Sekarang? Dipetik May 10, 2019 ,

dari https://www.liputan6.com/bisnis/read/2889969/ berapa-uang-saku-yang-wajar-untuk-anakzaman-sekarang

Zubaidah, N. (2019). Literasi Keuangan Harus Diajarkan Sejak Dini. Dipetik May 10, 2019, dari

https://economy.okezone.com/read/2019/02/21/ 320/2020972/literasi-keuangan-harus-diajarkansejak-dini 